\title{
Genetic Tools for the Conservation of Wild Asian Elephants
}

\author{
Chalita Kongrit ${ }^{1}$ \\ ${ }^{1}$ Department of Biology, Faculty of Science, Mahidol University, Thailand \\ Correspondence: Chalita Kongrit, Department of Biology, Faculty of Science, Mahidol University, Bangkok, \\ 10400, Thailand. Tel: 668-5906-1221. E-mail: ch.kongrit@gmail.com \\ Received: December 6, 2016 \\ Accepted: December 22, 2016 \\ Online Published: January 3, 2017 \\ doi:10.5539/ijb.v9n2p1 \\ URL: http://dx.doi.org/10.5539/ijb.v9n2p1
}

\begin{abstract}
The distribution of the Asian elephant (Elephas maximus) has been limited to the remaining discontinuous forests, mainly in the South and Southeast Asia. A global number of wild Asian elephants have been declining due to habitat loss, forest fragmentation, and anthropogenic disturbance. Acquiring information of wild populations is important for effective conservation and management plan. This article reviews the applications of noninvasive genetic method as a tool for studying wild Asian elephants. Noninvasive genetic method has been introduced to the field of wildlife conservation for more than two decades. The method provides reliable information of a population and facilitates investigation of genetic effects on small and fragmented populations. Various DNA markers for the Asian elephant, those include mitochondrial DNA, microsatellite DNA, and sex determination markers, have been developed and used to study wild elephant populations across the distribution range. Most of the studies revealed the issues of low genetic diversity in the small populations and interruption of gene flow among the fragmented populations. Tracking of ivory poaching has not yet been done in the Asian elephant. It could be carried out if a reference genetic database of the natural populations is available. Noninvasive genetic method has been proved to be a promising tool for conservation of the wild Asian elephants. Transboundary collaboration would give hope for a successful long-term conservation of this charismatic species in their natural habitats.
\end{abstract}

Keywords: Asian elephant, Elephas maximus, genetic diversity, noninvasive genetic method

\section{Introduction}

The Asian elephant, Elephas maximus, is an umbrella species in tropical forests. Wild elephants play important roles in a maintenance of forest dynamics such as opening animal trails in the forests, creating open gaps those facilitate seed germination (Sukumar, 2003), and acting as a seed disperser for large-seed fruit species (Kitamura, Yumoto, Poonswad, \& Wohandee, 2007). An estimated number of the total population was 39 463-47 427 (Fernando $\&$ Pastorini, 2011). The conservation status of the Asian elephant has been recognized as an endangered species since 1986 (Choudhury et al., 2008). Wild Asian elephants are currently distributed in 13 countries, mainly in the South and Southeast Asia (Santiapillai \& Jackson, 1990; Sukumar, 1992, 2003, 2006; Fernando \& Pastorini, 2011). India holds the world largest population of wild Asian elephants with an estimated number at 26 000-28 000 elephants (Baskaran, Varma, Sar, \& Sukumar, 2011). However, most of these elephants are distributed in fragmented landscape (Sukumar, 1992, 2003). There are significant numbers of wild Asian elephants of more than one thousand elephants in Sri Lanka (Fernando, Jayewardene, Prasad, Hendavitharana, \& Pastorini, 2011), Thailand (Srikrachang, 2003), Sumatra Island (Azmi \& Gunaryadi, 2011), peninsular Malaysia (Saaban, Othman, Yasak, Burhanuddin, \& Zafir, 2011), Borneo (Alfred, Ambu, Nathan, \& Goossens, 2011) and Myanmar (Leimgruber et al., 2011). Major threats to wild Asian elephants worldwide are habitat loss and fragmentation (Santiapillai \& Jackson, 1990), illegal poaching, and conflicts with human (Sukumar, 1992, 2003, 2006; Fernando \& Pastorini, 2011). These threats resulted in population decline, skewed sex ratio (Ramakrishnan, Santosh, Ramakrishnan, \& Sukumar, 1998; Vidya, Kumar, Arivazhagan, \& Sukumar, 2003; Moßbrucker et al., 2015), and disruption of social organization (Vidya, Varma, Dang, Thanh, \& Sukumar, 2007). Intensive studies on biology, ecology, behavior and genetic diversity of wild Asian elephants have been carried out in India and Sri Lanka, though such information in other countries is still limited. Fine-scale studies of elephant populations, their distribution and conservation issues in each country are indeed required for the conservation in a global scale. 
This article reviews the studies of wild Asian elephants in various aspects based on noninvasive genetic method, the important conservation issues of wild populations in different regions, and suggestions for long-term conservation of wild Asian elephants in natural habitat.

\section{Noninvasive Genetic Method for Wildlife Study}

Noninvasive genetic method has been developed and applied for wildlife studies for over two decades. Genetic materials of animals can be obtained from the samples that the animals deposit, such as feces, hair, and feather. The genetic method facilitates data obtaining that will be useful for management and conservation plan such as individual and sex identification, population size estimation, population sex ratio, genetic diversity, relatedness among individuals in a population, gene flow among populations, detection of bottleneck event, phylogeography of particular species, detection of hybridization, providing evidence of illegal wildlife poaching, including being a tool for genetic management of a population and a long-term monitoring of the managed population.

Study of wild elephants in tropical forests by a direct observation could be difficult due to dense vegetation. Alternative methods such as dung count (Hedges et al., 2005) and noninvasive genetic method (Ahlering et al., 2011; Hedges, Johnson, Ahlering, Tyson, \& Eggert, 2013; Gray, Vidya, Potdar, Bharti, \& Sovanna, 2014; Moßbrucker et al., 2015) have been applied to obtain data of wild elephant populations in such habitats. One of the advantages of noninvasive genetic method over the dung count method is that the genetic method provides genetic information of the populations that could not be obtained from field data collection alone. The genetic method also produced precise population size estimation with reasonable costs and time consumed (Hedges et al., 2013). However, it is important to note that in order to obtain reliable genetic results, fresh dung samples are required.

\section{Molecular Markers for the Asian Elephant}

\subsection{Mitochondrial DNA}

Various molecular markers have been specifically developed for the Asian elephant. Mitochondrial DNA is maternally inherited. It is a suitable DNA marker to refer genetics of maternal lineage and to study a population in evolutionary aspects such as evolutionary phylogeny and phylogeography (Fleischer, Perry, Muralidharan, Stevens, \& Wemmer, 2001; Fernando et al., 2003; Vidya, Sukumar, \& Melnick, 2009). DNA primers for amplification of the mitochondrial DNA fragment of the Asian elephant have been designed (Fernando \& Lande, 2000) and used to study mitochondrial haplotype distribution of wild populations across their range (Fleischer et al., 2001; Vidya et al., 2009), and in particular populations in Sri Lanka (Fernando, Pfrender, Encalada, \& Lande, 2000), India (Vidya, Fernando, Melnick, \& Sukumar, 2005b), Vietnam (Vidya et al., 2007), Laos (Ahlering et al., 2011), peninsular Malaysia (Elliza, Shukor, Othman, \& Md-Zain, 2015), Sumatra (Moßbrucker et al., 2015), and Borneo (Goossens et al., 2016). The primer pair designed by Fernando and Lande (2000) has been used in most of the studies, thus the variation of mitochondrial DNA of different populations could be directly compared.

\subsection{Microsatellite DNA}

Microsatellite DNA is a hypervariable, neutral and biparental inheritance markers. The marker is suitable for individual identification, parentage assignment and genetic analyses under Hardy-Weinberg assumptions in which a large and close population with a random mating system and no natural selection is assumed. Di-, tri- and tetranucleotide microsatellite DNA for the Asian elephant have been developed (Fernando, Vidya, \& Melnick, 2001; Kongrit et al., 2008). Multilocus microsatellite genotyping together with mark-recapture analyses allows researchers to reliably estimate population size (Hedges et al., 2013; Gray et al., 2014; Moßbrucker et al., 2015). Cross specific microsatellite primers developed for the African elephant (Loxodonta africana) have also been commonly applied to the Asian elephant populations (Vidya et al., 2007; Flagstad, Pradhan, Kvernstuen, \& Wegge, 2012; Moßbrucker et al., 2015). Note that null allele should be under concerned when cross specific primers are used. The presence of null alleles can be statistically estimated (van Oosterhout, Hutchinson, Wills, \& Shipley, 2004; Kalinowski \& Taper, 2006; Kalinowski, Taper, \& Marshall, 2007; Rousset, 2008).

\subsection{Sex Determination Markers}

Individual sex can be determined by amplification of sex determination regions on sex chromosomes (Fernando \& Melnick, 2001; Gupta, Thangaraj, \& Singh, 2006; Vidya et al., 2007; Munshi-South et al., 2008; Ahlering et al., 2011; Chakraborty, Boominathan, Desai, \& Vidya, 2014), thus the population sex ratio can be estimated (Vidya et al., 2003; Vidya et al., 2007; Ahlering et al., 2011; Flagstad et al., 2012; Chakraborty et al., 2014; Moßbrucker et al., 2015). 


\subsection{Single Nucleotide Polymorphisms (SNPs)}

Recently, the single nucleotide polymorphisms (SNPs) maker has been applied for evaluation and comparison of genetic diversity in the two populations of Bornean elephants (Goossens et al., 2016). The SNP loci used in the study were polymorphic and showed similar patterns of genetic diversity as those obtained from the microsatellite loci.

Combining different types of DNA markers allows researchers to investigate a population in fine-scale, such as relatedness among individuals within and between groups, social structure and genetic structure of the populations (Vidya et al., 2005b; Vidya et al., 2007; Goossens et al., 2016).

\subsection{Genotyping Errors Due to Noninvasive Sample Sources}

Most of the genetic studies of wild Asian elephants relied on elephant dung sample as a source of genetic material. Although noninvasive genetic technique provides a powerful method for wildlife study, this technique must be carried out with care. Degraded DNA may cause allelic dropout in which only one allele of a heterozygote is amplified. A heterozygote might be misinterpreted as a false homozygote. The "multiple tubes approach" (Taberlet et al., 1996) has been suggested to obtain true genotypes of the samples by separately re-extracting DNA and reamplifying microsatellite regions before combining the results. The "comparative approach" (Frantz et al., 2003) has been proposed and commonly used by repeating amplification of the microsatellite fragments and scoring the consensus genotypes (e.g. Ahlering et al., 2011; Flagstad et al., 2012; Gray et al., 2014). The analytic software has been developed to examine allelic dropout and null alleles, or to determine problematic loci (Valière, 2002; van Oosterhout et al., 2004; Mckelvey \& Schwartz, 2005; Rousset, 2008).

\section{Investigating Effects of Small Population Size, Habitat Fragmentation, and Anthropogenic Disturbance}

Habitat loss and fragmentation, anthropogenic disturbance, poaching and conflicts with human have been considered as important threats to the Asian elephants, resulting in population decline and fragmentation. Genetic diversity is an important factor for the evolution of populations in response to environmental change (Frankham, Briscoe, \& Ballou, 2002). Genetic analysis of wild populations revealed a positive correlation between genetic diversity and population size (Frankham, 1996). Although wild elephants could adapt to environmental disturbance and many populations are likely to be increasing, this does not guarantee long-term survival of the populations. Analyses of genetic diversity and gene flow among populations could help investigate the effects of habitat fragmentation and small population size, thus, guidelines for conservation could be designed based on the empirical information.

\subsection{Low Genetic Diversity in the Small Populations}

A small number of elephants were determined in Cat Tien National Park based on noninvasive genetic method (Vidya et al., 2007). Low mitochondrial and microsatellite diversity was observed in this population. The study also revealed disruption of social organization and biased sex ratio toward females. More than one mitochondrial haplotype was detected in a single elephant group which indicated that the members were not maternally related. Genetic relatedness among individuals of the same mitochondrial haplotype was much lower than expected relatedness among members of the same family. The authors suggested that anthropogenic disturbance in the past has affected their social organization. The elephants have formed a group and traveled together although they are not relatives. Integration of non-kin elephants from different social groups has also been reported in the African elephant populations in which more than one mitochondrial haplotypes was found in family units (Nyakaana, Abe, Arctander, \& Siegismund, 2001; Archie, Moss, \& Alberts, 2006; Wittemyer et al., 2009), possibly as a result of severe poaching. Analysis of genetic diversity revealed a history of the population in the Phnom Prich Wildlife Sanctuary, Cambodia. The population contained moderate to high microsatellite diversity, though deviation from Hardy-Weinberg equilibrium was detected, which is possibly due to population decline and fragmentation in the past (Gray et al., 2014).

\subsection{Population Fragmentation in Human-Dominated Areas}

Most of the elephant populations in Southeast Asia have been suffered from habitat conversion and disturbance by human activities. The habitat of the Bornean elephants those are distributed only in Borneo Island and considered as an evolutionarily significant unit (Fernando et al., 2003), was highly fragmented due to land conversion to palm oil plantations and human settlement. Genetic analysis of the Bornean elephants revealed low genetic diversity compared to that of other mainland Asian elephant populations (Goossens et al., 2016) such as populations in Laos (Ahlering et al., 2011) and Cambodia (Gray et al., 2014). Only one mitochondrial haplotype was found in the studied populations (Fernando et al., 2003; Goossens et al., 2016). A low but significant level of genetic differentiation was detected, possibly due to the existence of gene flow between populations within the region or recent fragmentation (Goossens et al., 2016). The Sumatran elephant (E. maximus sumatranus) is one of 
the three subspecies of the Asian elephant (Shoshani \& Eisenberg, 1982). Sumatran elephants are critically endangered and have received high priority for conservation due to a rapid decline in numbers. The largest known population of Sumatran in Bukit Tigapuluh landscape was genetically differentiated with two subpopulations determined in the landscape, and no observation of elephant traveling between subpopulations (Moßbrucker et al., 2015). The dominance of subadults age-class and strong biased sex ratio toward females might be a result of a long-time illegal killing of crop raid elephants and/or for ivory poaching (Moßbrucker et al., 2015).

Intensive studies in various aspects of the Asian elephant have been carried out in India. A total of eight mitochondrial haplotypes were detected across the populations in India, though the haplotype diversity in each region was very low with only 1-3 haplotypes found (Vidya et al., 2005b). Surprisingly, only one mitochondrial haplotype was fixed in Nilgiris (Vidya, Fernando, Melnick, \& Sukumar, 2005a, Vidya et al., 2005b, Vidya et al., 2009) which is the world's largest population of at least 9,000 free-ranging elephants. Fixed haplotype could possibly be due to elephant social structure in which maternally related groups formed clans over decades or centuries, or due to past bottlenecks (Vidya et al., 2005b). Biased sex ratio toward female suggested severe poaching for tuskers (Vidya et al., 2003). Fragmented populations in central and southern India were significantly differentiated (Vidya et al., 2005a). A gap between the mountain range and the river could be a biogeographic barrier to elephant movement in southern India (Vidya et al., 2005a). The genetic studies of elephant populations in India revealed the effects of habitat fragmentation on genetic diversity loss and interruption of gene flow within and among populations (Vidya et al., 2005a).

\subsection{Migration Facilitates Maintenance of Genetic Diversity}

In contrast to the large populations in India, smaller populations of mainland elephants in Nakai-Nam Theun National Protected area, Lao PDR, and peninsular Malaysia showed higher level of haplotype diversity than that of the populations in India with six (Ahlerling et al., 2011) and ten mitochondrial haplotypes determined (Elliza et al., 2015), respectively. Elliza et al. (2015) suggested that high level of haplotype diversity in peninsular Malaysia was possibly due to gene flow among populations in the peninsula. Although a small isolated population is generally prone to extinction, migrants from other population could help recover genetic diversity and growth of the population (Vilà et al., 2003; Madsen, Ujvari, \& Olsson, 2004). A nearly extinct elephant population in Bardia National Park, Nepal, has been reestablished by immigrants into the population (Flagstad et al., 2012). The study revealed biased sex ratio toward male in sub-adult age-class, and the analysis indicated immigration of sub-adult males into the population. The migrants were possibly from the Katarniaghat Wildlife Sanctuary or the Dudhwa National Park in India. Although the reestablished population was quite small with the estimated population size at 57 elephants, genetic diversity was fairly high (Flagstad et al., 2012).

\section{Tracking Illegal Hunting and Ivory Trade}

Ivory trade is a major conservation issue for both of the African and Asian elephant. Severe poaching for largesized tusks of the African elephant resulted in disruption of social organization (Nyakaana et al., 2001) while poachers targeted only male Asian elephants for their tusks, resulting in skewed sex ratio toward females in the populations (Vidya et al., 2003; Moßbrucker et al., 2015). Ivory poaching directly affects survivorship of tuskers. It was estimated that more than a hundred tuskers were killed every year during 1980s (Sukumar, 1992). Although mortality and survivorship of females and tuskless males are not directly affected by ivory poaching, selective killing of tuskers affects the demographic structure of elephant populations. The adult sex ratio of the population in Periyar Tiger Reserve, India, was highly skewed with 1 male: 100 females (Ramakrishnan et al., 1998). The sex ratios of wild elephants in Nagarahole and Mudumalai-Bandipur reserves in 2001 were biased toward females, 1 male: 3.1 females, and 1 male: 9.4 females, respectively (Vidya et al., 2003). Selective killing of tuskers may lead to inbreeding and loss of genes in the population.

Genetic tools can provide information on species identification and origin populations of the seized ivory. A quality of genomic DNA obtained from tusk samples was sufficient for amplification of mitochondrial and microsatellite DNA fragments (Comstock, Ostrander, \& Wasser, 2003; Wasser et al., 2008). A reference database of mitochondrial haplotype and microsatellite diversity of the known geographic origin of 399 elephant samples has been constructed (Wasser et al., 2004). Ivory seized during shipment has been species identified and assigned for their origins (Wasser et al., 2007; Wasser et al., 2008).

Assignment of seized Asian elephant ivory to its origin populations has not yet been carried out. A reference database of known location samples and hypervariable DNA markers is required. Since Asian elephants have a long-time history close to human culture and have been transported throughout the range, a challenge to create such reference database is obtaining certainly known origin samples. To achieve this goal, international collaboration among 13 countries of their distribution range is required. 


\section{Summary and the Next Challenges for the Conservation of Wild Asian Elephants}

Genetic tools and noninvasive approaches have been proved to be useful for wildlife research and conservation, especially for obtaining genetic information of individuals and populations. Genetic studies of wild Asian elephants revealed effects of small population size, population fragmentation, sex-biased poaching of male Asian elephants, and anthropogenic disturbance of the habitats that is likely to increase a risk of population decline and extinction. Habitat management to facilitate gene flow among fragmented populations and introduction of migrants into a small population could increase genetic diversity of the population, lower risk of inbreeding and promote population growth (Vilà et al., 2003; Madsen et al., 2004). Although the remaining habitats are fragmented and have been disturbed, wild elephants quite tolerate to habitat disturbance. They can adapt and live in disturbed habitats as long as there is enough food and water available for living. Management of the fragmented populations as metapopulation has been purposed for the conservation of African elephants (van Aarde \& Jackson, 2007). This approach would be a good strategy to conserve fragmented populations of wild Asian elephants.

Population structure and genetic database of the wild populations need to be established for long-term monitoring of changes in population structure and genetic diversity. If the same set of DNA markers can be used for the construction of the reference database, comparison of genetic diversity among different populations and assignment of the confiscated samples to the origin populations would be practical. The next challenges for conservation of wild Asian elephants would be the management to maintain wild elephants in the remaining natural habitats, protection of wild elephants from illegal poaching and establishment of collaboration for elephant conservation in regional scale.

\section{Acknowledgements}

I thank C. Siripunkaw for valuable comments on the manuscript.

\section{References}

Ahlering, M. A., Hedges, S., Johnson, A., Tyson, M., Schuttler, S. G., \& Eggert, L. S. (2011). Genetic diversity, social structure, and conservation value of the elephants of the Nakai Plateau, Lao PDR, based on noninvasive sampling. Conservation Genetics, 12(2), 413-422. https://doi.org/10.1007/s10592-010-0148-y

Alfred, R., Ambu, L., Nathan, S., \& Goossens, B. (2011). Current status of Asian elephants in Borneo. Gajah, 35, 29-35.

Archie, E. A., Moss, C. J., \& Alberts, S. C. (2006). The ties that bind: Genetic relatedness predicts the fission and fusion of social groups in wild African elephants. Proceedings of the Royal Society B: Biological Sciences, 273(1586), 513-522. https://doi.org/10.1098/rspb.2005.3361

Azmi, W., \& Gunaryadi, D. (2011). Current status of Asian elephants in Indonesia. Gajah, 35, 55-61.

Baskaran, N., Varma, S., Sar, C. K., \& Sukumar, R. (2011). Current status of Asian elephants in India. Gajah, 35, 47-54.

Chakraborty, S., Boominathan, D., Desai, A. A., \& Vidya, T. N. C. (2014). Using genetic analysis to estimate population size, sex ratio, and social organization in an Asian elephant population in conflict with humans in Alur, southern India. Conservation Genetics, 15(4), 897-907. https://doi.org/10.1007/s10592-014-0587-y

Choudhury, A., Lahiri Choudhury, D. K., Desai, A., Duckworth, J. W., Easa, P. S., Johnsingh, A. J. T., ... Karanth, U. (2008). Elephas maximus. The IUCN Red List of Threatened Species. Retrieved September 3, 2010, from http://dx.doi.org/10.2305/IUCN.UK.2008.RLTS.T7140A12828813.en

Comstock, K. E., Ostrander, E. A., \& Wasser, S. K. (2003). Amplifying nuclear and mitochondrial DNA from African elephant ivory: A tool for monitoring the ivory trade. Conservation Biology, 17(6), 1840-1843. https://doi.org/10.1111/j.1523-1739.2003.00358.x

Elliza, M. N., Shukor, M. N., Othman, N., \& Md-Zain, B. M. (2015). Haplotype distribution among endangered Asian elephants (Elephas maximus) in Peninsular Malaysia. Malaysian Applied Biology, 44(2), 129-135.

Fernando, P., Jayewardene, J., Prasad, T., Hendavitharana, W., \& Pastorini, J. (2011). Current status of Asian elephants in Sri Lanka. Gajah, 35, 93-103.

Fernando, P., \& Lande, R. (2000). Molecular genetic and behavioral analysis of social organization in the Asian elephant (Elephas maximus). Behavioral Ecology and Sociobiology, 48(1), 84-91. https://doi.org/10.1007/ s002650000218

Fernando, P., \& Melnick, D. J. (2001). Molecular sexing eutherian mammals. Molecular Ecology Notes, 1(4), 350353. https://doi.org/10.1046/j.1471-8278.2001.00112.x 
Fernando, P., \& Pastorini, J. (2011). Range-wide status of Asian elephants. Gajah, 35, 15-20.

Fernando, P., Pfrender, M. E., Encalada, S. E., \& Lande, R. (2000). Mitochondrial DNA variation, phylogeography and population structure of the Asian elephant. Heredity, 84(3), 362-372. https://doi.org/10. 1046/j.13652540.2000.00674.x

Fernando, P., Vidya, T. N. C., \& Melnick, D. J. (2001). Isolation and characterization of tri- and tetranucleotide microsatellite loci in the Asian elephant, Elephas maximus. Molecular Ecology Notes, 1(4), $232-233$. https://doi.org/10.1046/j.1471-8278.2001.00082.x

Fernando, P., Vidya, T. N. C., Payne, J., Stuewe, M., Davison, G., Alfred, R. J., ... Melnick, D. J. (2003). DNA analysis indicates that Asian elephants are native to Borneo and are therefore a high priority for conservation. PLoS Biology, 1(1). https://doi.org/10.1371/journal.pbio.0000006

Flagstad, Ø., Pradhan, N. M. B., Kvernstuen, L. G., \& Wegge, P. (2012). Conserving small and fragmented populations of large mammals: Non-invasive genetic sampling in an isolated population of Asian elephants in Nepal. Journal for Nature Conservation, 20(3), 181-190. https://doi.org/10.1016/j.jnc.2012.01.006

Fleischer, R. C., Perry, E. A., Muralidharan, K., Stevens, E. E., \& Wemmer, C. M. (2001). Phylogeography of the Asian elephant (Elephas maximus) based on mitochondrial DNA. Evolution, 55(9), 1882-1892. https://doi.org/10.1111/j.0014-3820.2001.tb00837.x

Frankham, R. (1996). Relationship of genetic variation to population size in wildlife. Conservation Biology, 10(6), 1500-1508. https://doi.org/10.1046/j.1523-1739.1996.10061500.x

Frankham, R., Briscoe, D. A., \& Ballou, J. D. (2002). Introduction to conservation genetics: Cambridge University Press. https://doi.org/10.1017/CBO9780511808999

Frantz, A. C., Pope, L. C., Carpenter, P. J., Roper, T. J., Wilson, G. J., Delahay, R. J., \& Burke, T. (2003). Reliable microsatellite genotyping of the Eurasian badger (Meles meles) using faecal DNA. Molecular Ecology, 12(6), 1649-1661. https://doi.org/10.1046/j.1365-294X.2003.01848.X

Goossens, B., Sharma, R., Othman, N., Kun-Rodrigues, C., Sakong, R., Ancrenaz, M., ... Chikhi, L. (2016). Habitat fragmentation and genetic diversity in natural populations of the Bornean elephant: Implications for conservation. Biological Conservation, 196, 80-92. https://doi.org/10.1016/j.biocon.2016.02.008

Gray, T. N. E., Vidya, T. N. C., Potdar, S., Bharti, D. K., \& Sovanna, P. (2014). Population size estimation of an Asian elephant population in eastern Cambodia through non-invasive mark-recapture sampling. Conservation Genetics, 15(4), 803-810. https://doi.org/10.1007/s10592-014-0579-y

Gupta, S. K., Thangaraj, K., \& Singh, L. (2006). A simple and inexpensive molecular method for sexing and identification of the forensic samples of elephant origin. Journal of Forensic Sciences, 51(4), 805-807. https://doi.org/10.1111/j.1556-4029.2006.00154.x

Hedges, S., Johnson, A., Ahlering, M., Tyson, M., \& Eggert, L. S. (2013). Accuracy, precision, and costeffectiveness of conventional dung density and fecal DNA based survey methods to estimate Asian elephant (Elephas maximus) population size and structure. Biological Conservation, 159, 101-108. https://doi.org/10.1016/j.biocon.2012.12.010

Hedges, S., Tyson, M. J., Sitompul, A. F., Kinnaird, M. F., Gunaryadi, D., \& Aslan. (2005). Distribution, status, and conservation needs of Asian elephants (Elephas maximus) in Lampung Province, Sumatra, Indonesia. Biological Conservation, 124(1), 35-48. https://doi.org/10.1016/j.biocon.2005.01.004

Kalinowski, S. T., \& Taper, M. L. (2006). Maximum likelihood estimation of the frequency of null alleles at microsatellite loci. Conservation Genetics, 7(6), 991-995. https://doi.org/10.1007/s10592-006-9134-9

Kalinowski, S. T., Taper, M. L., \& Marshall, T. C. (2007). Revising how the computer program CERVUS accommodates genotyping error increases success in paternity assignment. Molecular Ecology, 16(5), 1099 1106. https://doi.org/10.1111/j.1365-294X.2007.03089.x

Kitamura, S., Yumoto, T., Poonswad, P., \& Wohandee, P. (2007). Frugivory and seed dispersal by Asian elephants, Elephas maximus, in a moist evergreen forest of Thailand. Journal of Tropical Ecology, 23(03), 373-376. https://doi.org/10.1017/S0266467407004026

Kongrit, C., Siripunkaw, C., Brockelman, W. Y., Akkarapatumwong, V., Wright, T. F., \& Eggert, L. S. (2008). Isolation and characterization of dinucleotide microsatellite loci in the Asian elephant (Elephas maximus). Molecular Ecology Resources, 8(1), 175-177. https://doi.org/10.1111/j.1471-8286.2007.01916.x 
Leimgruber, P., Oo, Z. M., Aung, M., Kelly, D. S., Wemmer, C., Senior, B., \& Songer, M. (2011). Current status of Asian elephants in Myanmar. Gajah 35, 35, 76-86.

Madsen, T., Ujvari, B., \& Olsson, M. (2004). Novel genes continue to enhance population growth in adders (Vipera berus). Biological Conservation, 120(1), 145-147. https://doi.org/10.1016/j.biocon.2004.01.022

McKelvey, K. S., \& Schwartz, M. K. (2005). DROPOUT: a program to identify problem loci and samples for noninvasive genetic samples in a capture-mark-recapture framework. Molecular Ecology Notes, 5(3), 716718. https://doi.org/10.1111/j.1471-8286.2005.01038.x

Moßbrucker, A. M., Apriyana, I., Fickel, J. r., Imron, M. A., Pudyatmoko, S., Sumardi, \& Suryadi, H. (2015). Non-Invasive Genotyping of Sumatran elephants: Implications for Conservation. Tropical Conservation Science, 8(3), 745-759. https://doi.org/10.1177/194008291500800312

Munshi-South, J., Tchignoumba, L., Brown, J., Abbondanza, N., Maldonado, J. E., Henderson, A., \& Alonso, A. (2008). Physiological indicators of stress in African forest elephants (Loxodonta africana cyclotis) in relation to petroleum operations in Gabon, Central Africa. Diversity and Distributions, 14(6), 995-1003. https://doi.org/10.1111/j.1472-4642.2008.00509.x

Nyakaana, S., Abe, E. L., Arctander, P., \& Siegismund, H. R. (2001). DNA evidence for elephant social behavior breakdown in Queen Elizabeth National Park, Uganda. Animal Conservation, 4, 231-237. https://doi.org/10. 1017/ S1367943001001275

Ramakrishnan, U., Santosh, J. A., Ramakrishnan, U., \& Sukumar, R. (1998). The population and conservation status of Asian elephants in the Periyar Tiger Reserve, southern India. Current Science, 74, 110-113.

Rousset, F. (2008). GENEPOP'007: a complete reimplementation of the GENEPOP software for Windows and Linux. Molecular Ecology Resources, 8, 103-106. https://doi.org/10.1111/j.1471-8286.2007.01931.x

Saaban, S., Othman, N. B., Yasak, M. N. B., Burhanuddin, M. N., \& Zafir, A. (2011). Current status of Asian elephants in Peninsular Malaysia. Gajah, 35, 67-75.

Santiapillai, C., \& Jackson, P. (1990). The Asian elephant: an action plan for its conservation. Gland, Switzerland: IUCN.

Shoshani, J., \& Eisenberg, J. F. (1982). Elephas maximus. Mammalian Species, 182, 1-8. https://doi.org/10.2307/ 3504045

Srikrachang, M. (2003). Conservation and management of elephants in Thailand. (Unpublished doctoral thesis), Mahidol University, Bangkok, Thailand.

Sukumar, R. (1992). The Asian elephant: Ecology and management: Cambridge University Press.

Sukumar, R. (2003). The living elephant: Evolutionary ecology, behavior and conservation: Oxford University Press

Sukumar, R. (2006). A brief review of the status, distribution and biology of wild Asian elephants Elephas maximus. International Zoo Yearbook, 40(1), 1-8. https://doi.org/10.1111/j.1748-1090.2006.00001.x

Taberlet, P., Griffin, S., Goossens, B. t., Questiau, S., Manceau, V. r., Escaravage, N., ... Bouvet, J. (1996). Reliable genotyping of samples with very low DNA quantities using PCR. Nucleic Acids Research, 24(16), 31893194. https://doi.org/10.1093/nar/24.16.3189

Valière, N. (2002). GIMLET: a computer program for analysing genetic individual identification data. Molecular Ecology Notes, 2(3), 377-379. https://doi.org/10.1046/j.1471-8286.2002.00228.x-i2

van Aarde, R. J., \& Jackson, T. P. (2007). Megaparks for metapopulations: Addressing the causes of locally high elephant numbers in southern Africa. Biological Conservation, 134(3), 289-297. https://doi.org/10.1016/ j.biocon.2006.08.027

van Oosterhout, C., Hutchinson, W. F., Wills, D. P. M., \& Shipley, P. (2004). MICRO-CHECKER: software for identifying and correcting genotyping errors in microsatellite data. Molecular Ecology Notes, 4(3), 535-538. https://doi.org/10.1111/j.1471-8286.2004.00684.x

Vidya, T. N. C., Fernando, P., Melnick, D. J., \& Sukumar, R. (2005a). Population differentiation within and among Asian elephant (Elephas maximus) populations in southern India. Heredity, 94(1), 71-80. https://doi.org/10. 1038/sj.hdy.6800568 
Vidya, T. N. C., Fernando, P., Melnick, D. J., \& Sukumar, R. (2005b). Population genetic structure and conservation of Asian elephants (Elephas maximus) across India. Animal Conservation, 8(4), 377-388. https://doi.org/10.1017/S1367943005002428

Vidya, T. N. C., Kumar, V. R., Arivazhagan, C., \& Sukumar, R. (2003). Application of molecular sexing to freeranging Asian elephant (Elephas maximus) populaitons in Southern India. Current Science, 85(7), 1074-1077.

Vidya, T. N. C., Sukumar, R., \& Melnick, D. J. (2009). Range-wide mtDNA phylogeography yields insights into the origins of Asian elephants. Proceedings of the Royal Society B: Biological Sciences, 276(1658), 893-902. https://doi.org/10.1098/rspb.2008.1494

Vidya, T. N. C., Varma, S., Dang, N. X., Thanh, T. V., \& Sukumar, R. (2007). Minimum population size, genetic diversity, and social structure of the Asian elephant in Cat Tien National Park and its adjoining areas, Vietnam, based on molecular genetic analyses. Conservation Genetics, 8, 1471-1478. https://doi.org/10. 1007/s10592-007-9301-7

Vilà , C., Sundqvist, A. K., Flagstad, Ø., Seddon, J., rnerfeldt, S. B., Kojola, I., ... Ellegren, H. (2003). Rescue of a severely bottlenecked wolf (Canis lupus) population by a single immigrant. Proceedings of the Royal Society of London B: Biological Sciences, 270(1510), 91-97. https://doi.org/10.1098/rspb.2002.2184

Wasser, S. K., Joseph Clark, W., Drori, O., Stephen Kisamo, E., Mailand, C., Mutayoba, B., \& Stephens, M. (2008). Combating the illegal trade in African elephant ivory with DNA forensics. Conservation Biology, 22(4), 1065-1071. https://doi.org/10.1111/j.1523-1739.2008.01012.x

Wasser, S. K., Mailand, C., Booth, R., Mutayoba, B., Kisamo, E., Clark, B., \& Stephens, M. (2007). Using DNA to track the origin of the largest ivory seizure since the 1989 trade ban. Proceedings of the National Academy of Sciences of the United States of America, 104(10), 4228-4233. https://doi.org/10.1073/pnas.0609714104

Wasser, S. K., Shedlock, A. M., Comstock, K., Ostrander, E. A., Mutayoba, B., \& Stephens, M. (2004). Assigning African elephant DNA to geographic region of origin: applications to the ivory trade. Proceedings of the National Academy of Sciences of the United States of America, 101(41), 14847-14852. https://doi.org/10. 1073/pnas.0403170101

Wittemyer, G., Okello, J. B. A., Rasmussen, H. B., Arctander, P., Nyakaana, S., Douglas-Hamilton, I., \& Siegismund, H. R. (2009). Where sociality and relatedness diverge: The genetic basis for hierarchical social organization in African elephants. Proceedings of the Royal Society of London B: Biological Sciences, 276, 3513-3521. https://doi.org/10.1098/rspb.2009.0941

\section{Copyrights}

Copyright for this article is retained by the author(s), with first publication rights granted to the journal.

This is an open-access article distributed under the terms and conditions of the Creative Commons Attribution license (http://creativecommons.org/licenses/by/4.0/). 